\title{
Serum Insulin-Like Growth Factor (IGF) Binding Protein-3 and IGF-I Levels during Childhood and Adolescence. A Cross-Sectional Study
}

\author{
M. AMALIA ANDRADE OLIVIÉ, RICARDO V. GARCÍA-MAYOR, DOMINGO GONZÁLEZ \\ LESTÓN, TERESA RODRÍGUEZ SOUSA, ANA SEGURA DOMINGUEZ, \\ RAMÓN ALVAREZ-NOVOA, AND JESÚS ANTELO CORTIZAS \\ Clinical Chemistry Laboratory [M.A.A.O., T.R.S., A.S.D., R.A.-N.], Endocrine Division [R.V.G.-M.], and \\ Pediatric Service [D.G.L., J.A.C.], Hospital Xeral, Vigo, Spain
}

\begin{abstract}
To investigate the effect of pubertal development on serum levels of IGF binding protein-3 (IGFBP-3) and IGF-I, and the relationship between IGFBP-3 levels and height, weight, weight for height and age (WFHA), and IGF-I levels, a cross-sectional study was performed in a Spanish basic education school in Vigo (NW Spain). The study was made up of 181 girls with a mean chronologic age of $11.03 \pm 0.22 \mathrm{y}$ and 173 boys with a mean chronologic age of $10.9 \pm 0.23 \mathrm{y}$. The pubertal development was graded into three groups according to estradiol and testosterone concentrations for girls and boys, respectively. All subjects were in good health and among the 5th and 95th percentile for height. Serum IGFBP-3 and plasma IGF-I concentration was determined by RIA. Pubertal development was significantly associated with IGFBP-3 and IGF-I concentrations in girls and boys, respectively $(p<0.0001$, analysis of variance). Multivariate regression analyses between IGF-I or IGFBP-3 with age, sex, and estradiol or testosterone show significative correlation in prepubertal children for IGF-I $(r=0.545, p=0.0001$ and $r=0.574, p=0.0001$ for girls and boys, respectively) and only in prepubertal boys for IGFBP-3 $(r=0.336, p=0.0012)$. The linear correlation between IGF-I and IGFBP-3 was significant in both prepubertal
\end{abstract}

ABSTRACT

IGFBP-3 is one of a family of structurally related proteins that bind IGF peptides with high affinity and modifies their biologic actions (1-4). The biologic importance of IGFBP-3 presumably relates to its ability to bind IGF peptide and modify IGF bioavailability and bioactivity. There is general agreement that plasma IGFBP-3 prolongs the half-life of the IGFs in the circulation, limits extra vascular transit, and serves as a reservoir for these essential growth factors $(1,3,5)$. Unlike IGF-I, IGFBP-3 circulates in high concentration $(\mathrm{mg} / \mathrm{L})$ and can be

Reccived February 1, 1994; accepted February 21, 1995

Correspondence: M. Amalia Andrade Olivić, P.O. Box 1691, 36201 Vigo, España. Supported by a grant from the "Fondo de Investigaciones Sanitarias." Spanish Health Ministery, FIS: 93/115. $(r=0.25, p<0.0001)$ and pubertal $(r=0.40, p<0.0001)$ girls, but only in prepubertal boys $(r=0.30, p<0.0001)$. Stepwise regression analysis between SD score (SDS)-IGFBP-3 or SDSIGF-I as independent variables and height-SDS, weigh-SDS, WFHA, and age as dependent variables, show that IGFBP-3 or IGF-I are significantly correlated to WFHA only in prepubertal children. Present data suggest that interpretation of IGFBP-3 concentrations during adolescence requires knowledge of gonadal steroid levels, and the determination of IGFBP-3 level is a useful parameter for clinical proposes mainly in prepubertal children. (Pediatr Res 38: 149-155, 1995)

\section{Abbreviations}

IGFBP-3, IGF binding protein-3

WFHA, weight for height age

$\mathbf{E}_{2}$, estradiol

$\mathrm{T}$, testosterone

GH, growth hormone

SDS, SD score

$\mathbf{C V}$, coefficient of variance

ANOVA, analysis of variance

reliably assayed from a small sample volume. Like IGF-I, IGFBP-3 is influenced by GH secretory status (6-8).

During puberty an activation of the hypothalamohypophyseal-gonadal axis occurs and major alterations take place in the GH-IGF axis (9). Recent data show a distinct rise in IGF-I and IGFBP-3 concentrations during the adolescent age range. This spectacular rise is better associated with the stage of puberty than with chronologic age $(10,11)$.

Nutrition has profound effects on the GH-IGF-I axis (12). Studies on severe malnutrition in children revealed low IGF-I concentrations in these subjects (13). The data imply that serum IGF-I reflect nutritional status, and some authors have suggested that serum IGF-I be used to monitor nutritional intervention in acutely ill adults $(14,15)$. The effects of nutri- 
tion on IGF-I and IGFBP-3 in normal adolescents of both sexes have not been studied in detail.

The goal of this study was to investigate the effect of pubertal development on serum levels of IGFBP-3 and IGF-I, and the relationship between IGFBP-3 levels and height, weight, body composition, sex steroid levels, nutritional state, and IGF-I levels in a school-based sample of prepubertal and pubertal normal children.

\section{METHODS}

Subjects. This cross-sectional study was made up of healthy children from a Spanish basic education school in Vigo City. The school was selected at random from all State Schools in the City. All first to eighth grade girls and boys were invited to participate. Of 447 eligible students 326 (165 girls and 161 boys), whose parents had given their consent before starting the study, were included. At least $73 \%$ of all pupils from each academic level were studied. A group of 28 kindergarten children (13 girls and 15 boys) of the same Centre was also included. From the total of 354 pupils, 173 boys had a mean chronologic age of $10.9 \pm 0.23 \mathrm{y}$, ranging from 4.1 to $15.9 \mathrm{y}$, and 181 girls had a mean chronologic age of $11.03 \pm 0.22 \mathrm{y}$, ranging from 3.4 to $16.1 \mathrm{y}$. The study was approved by the General Hospital Ethical Committee, and informed consent was obtained from the children's parents.

To assess the effect of age on IGF-I and IGFBP-3, we grouped the subjects in four groups: $3-5$ y, $6-8$ y, 9-11 y, and 12-15 y.

Children were grouped according to their stage of pubertal development. Pubertal stages were established based on $\mathrm{T}$ and $\mathrm{E}_{2}$ levels for boys and girls, respectively. The cut-off for prepubertal and pubertal stages for either $T$ and $E_{2}$ were previously determined in a sample of 186 children ( 90 boys and 96 girls) from our normal pediatric population. Three groups of children (P1-P3) were studied. The P1 group consisted of 116 prepubertal boys with $T$ levels of less than 1.74 $\mathrm{nmol} / \mathrm{L}$, and 74 prepubertal girls with $\mathrm{E}_{2}$ levels of less than $36.57 \mathrm{pmol} / \mathrm{L}$. The $\mathrm{P} 2$ group consisted of eight early pubertal boys with $\mathrm{T}$ levels from 1.74 to $5.21 \mathrm{nmol} / \mathrm{L}$, and 23 early pubertal girls with $\mathrm{E}_{2}$ levels from 36.68 to $91.69 \mathrm{pmol} / \mathrm{L}$. The P3 group consisted of 50 overt pubertal boys with T levels of more than $5.21 \mathrm{nmol} / \mathrm{L}$, and 83 overt pubertal girls with $\mathrm{E}_{2}$ levels of more than $91.69 \mathrm{pmol} / \mathrm{L}$. The baseline characteristics of these groups are described in Table 1.
Auxologic measurements. Standing height was measured using a portable direct reading Harpenden stadiometer. Weight was determined for the children without shoes or coats using a calibrated electronic scale. To study the effect of stature, height was expressed as SDS for chronologic age, using the TannerWhitehouse standards (1975).

To evaluate the influence of nutritional state, weight was expressed as percentage of median WFHA, using the TannerWhitehouse standards (1975).

Samples. Morning blood samples ( $0900-1100$ h) were taken during two school visits. Blood was obtained by standard venipuncture technique, and after clotting at $4^{\circ} \mathrm{C}$ and separation by centrifugation, was frozen at $-20^{\circ} \mathrm{C}$ until being assayed in the same run.

Assay methods. Serum level of IGFBP-3 was assayed after a 561-fold dilution by RIA using a commercial kit (Mediagnost $\mathrm{GmbH}, \mathrm{FRG}$ ). The sensitivity of the assay was $0.06 \mu \mathrm{g} / \mathrm{L}$, and half-maximum displacement occurred at $6 \mu \mathrm{g} / \mathrm{L}$. The maximal interassay $\mathrm{CV}$ was $5.9 \%$ and the maximal intraassay $\mathrm{CV}$ was $3 \%$. Serum levels of IGFBP-3 were expressed as SDS (SDSIGFBP3) for chronologic age, using our levels of reference.

Plasma IGF-I concentration was determined by RIA using a commercial kit (Nichols Institute Diagnostic, San Juan Capistrano, CA) after plasma was subjected to an extraction technique (acid-ethanol precipitation) that removed binding proteins. The recovery from acid-ethanol extraction was from 89 to $105 \%$. The sensitivity was the $0.06 \mu \mathrm{g} / \mathrm{L}$. The maximal interassay $\mathrm{CV}$ was $6.8 \%$, and the maximal intraassay $\mathrm{CV}$ was $3.2 \%$. Serum levels of IGF-I were expressed as SD score (SDS-IGFI) for chronologic age, using our levels of reference.

Total $\mathrm{T}$ levels were measured by solid-phase RIA using a commercial kit (Coat-A-Count, Diagnostic Products Corp., Los Angeles, CA). The sensitivity was $0.138 \mathrm{pmol} / \mathrm{L}(0.04$ $\mathrm{ng} / \mathrm{mL}$ ). The maximal interassay $\mathrm{CV}$ was $7.9 \%$, and the maximal intraassay CV was $4.9 \%$.

$\mathrm{E}_{2}$ in serum was determined by solid-phase RIA using a commercial kit (Coat-A-Count, Diagnostic Products Corp.). The sensitivity was $18,355 \mathrm{pmol} / \mathrm{L}(5 \mathrm{pg} / \mathrm{mL})$; the maximal inter assay $\mathrm{CV}$ was $5.5 \%$ and the maximal intraassay $\mathrm{CV}$ was $2.8 \%$.

Serum albumin as a biochemical indicator of the nutritional state, was measured by green of bromocresol automated analysis by Hitachi System 717 (Boehringer Mannheim, GmbH, FRG).

Table 1. Clinical characteristics of the three groups studied

\begin{tabular}{|c|c|c|c|c|c|c|}
\hline \multirow[b]{2}{*}{ Characteristic } & \multicolumn{2}{|c|}{ P1. Prepubertal } & \multicolumn{2}{|c|}{ P2. Early pubertal } & \multicolumn{2}{|c|}{ P3. Overt pubertal } \\
\hline & $\begin{array}{c}\text { Girls } \\
(n=74)\end{array}$ & $\begin{array}{c}\text { Boys } \\
(n=116)\end{array}$ & $\begin{array}{c}\text { Girls } \\
(n=23)\end{array}$ & $\begin{array}{c}\text { Boys } \\
(n=8)\end{array}$ & $\begin{array}{c}\text { Girls } \\
(n=83)\end{array}$ & $\begin{array}{c}\text { Boys } \\
(n=50)\end{array}$ \\
\hline Age (y) & $8.31 \pm 0.29$ & $9.50 \pm 0.24$ & $12.17 \pm 0.39$ & $12.37 \pm 0.23$ & $13.12 \pm 0.16$ & $13.93 \pm 0.15$ \\
\hline SDS-height & $-0.29 \pm 0.09$ & $-0.39 \pm 0.12$ & $-0.02 \pm 0.47$ & $-0.46 \pm 0.24$ & $-0.16 \pm 0.21$ & $-0.39 \pm 0.15$ \\
\hline SDS-weight & $0.54 \pm 0.11$ & $0.06 \pm 0.09$ & $0.32 \pm 0.29$ & $0.36 \pm 0.24$ & $0.86 \pm 0.18$ & $0.33 \pm 0.12$ \\
\hline WFHA & $110.12 \pm 1.63$ & $103.20 \pm 1.55$ & $106.42 \pm 4.97$ & $110.54 \pm 23.76$ & $115.87 \pm 2.78$ & $109.64 \pm 2.19$ \\
\hline Albumin $(g / L)$ & $44.84 \pm 0.29$ & $44.74 \pm 0.19$ & $45.51 \pm 0.37$ & $44.46 \pm 0.74$ & $45.89 \pm 0.25$ & $45.71 \pm 0.28$ \\
\hline $\mathrm{T}(\mathrm{nmol} / \mathrm{L})$ & & $0.31 \pm 0.03$ & & $3.52 \pm 0.35$ & & $12.79 \pm 0.61$ \\
\hline $\mathrm{E}_{2}(\mathrm{pmol} / \mathrm{L})$ & $18.91 \pm 0.26$ & & $61.83 \pm 3.06$ & $27.79 \pm 5.96$ & $231.99 \pm 20.96$ & $49.39 \pm 4.33$ \\
\hline
\end{tabular}

Values are mean \pm SEM. 
Statistics. Data less than assay sensitivity were assigned the value of assay sensitivity. The data were analyzed using Statview SE + Graphics for Macintosh. Results are expressed as mean \pm SEM. The effect of gender and pubertal stage on IGFBP-3 and IGF-I levels, and differences between the experimental groups were evaluated by a one-way ANOVA, followed by Scheffe's $F$ test). Due to IGF-I and IGFBP-3 being log-normal distributed, we also used log IGF-I and log IGFBP-3 for the relationship between both parameters. The effect of $\mathrm{E}_{2}$ or $\mathrm{T}$ on IGFBP-3 or IGF-I was examined by multiple regression analyses including age. The effects of age, height-SDS, weight-SDS, and WFHA, and the relationships between the levels of IGFBP3-SDS and IGF-I-SDS were examined by simple linear regression, multiple linear regression, and stepwise logistic regression analyses. $p$ values less than 0.05 were considered significant.

\section{RESULTS}

Relationship between chronologic age and IGF-I or IGFBP-3. The mean \pm SEM levels of IGFBP-3 and IGF-I in the children's population studied is displayed against age for the four age groups (Fig. 1, $a$ and $b$ ). Serum IGFBP-3 levels in normal children showed a significant increase from the age of 12 y (ANOVA, $p<0.001$ ). Plasma IGF-I levels in boys followed a pattern similar to that for IGFBP-3, in contrast IGF-I levels increases earlier in girls (ANOVA, $p<0.001$ ). The data for IGF-I and IGFBP-3 are displayed against age as a continuous variable in (Fig. 2).

A significative linear correlation between chronologic age and IGF-I $(r=0.671, p<0.0001)$ or IGFBP-3 $(r=0.469, p<$
0.0001 ) in the whole sample population was found. When subjects were divided according to their gonadal development, significative correlations between chronologic age and IGF-I were observed only in prepubertal girls and boys $(r=0.467$, $p<0.0001$ and $r=0.519, p<0.0001$, respectively). Moreover, a significative weak correlation between chronologic age and IGFBP-3 was observed only in prepubertal boys $(r=$ $0.217, p=0.019$ ).

Effect of puberty. Pubertal development was significantly associated with IGFBP-3 concentration in boys and girls. Among prepubertal children IGFBP-3 levels were $3.56 \pm 0.08$ $\mathrm{mg} / \mathrm{L}$ and $3.48 \pm 0.07 \mathrm{mg} / \mathrm{L}$ for girls and boys, respectively. Among fully mature children IGFBP-3 were significantly higher than among prepubertal children; $4.75 \pm 0.09 \mathrm{mg} / \mathrm{L}$ and $4.65 \pm 0.11 \mathrm{mg} / \mathrm{L}$ for girls and boys, respectively, $p<0.0001$, ANOVA (Fig. 3).

Moreover, pubertal development was also significantly associated with IGF-I. Among prepubertal children IGF-I concentrations were $178.8 \pm 8.82 \mu \mathrm{g} / \mathrm{L}$ and $166.7 \pm 6.58 \mu \mathrm{g} / \mathrm{L}$ for girls and boys, respectively. Among fully mature subjects IGF-I concentrations were significantly higher than among prepubertal children, $490.26 \pm 16.12 \mu \mathrm{g} / \mathrm{L}$ and $448.28 \pm$ $17.37 \mu \mathrm{g} / \mathrm{L}$ for girls and boys, respectively, $p<0.0001$, ANOVA (Fig. 4). Significative differences between the mean \pm SEM values of early pubertal and prepubertal girls were observed for IGF-I levels but not for IGFBP-3 levels.

Significative simple linear correlations between $\mathrm{E}_{2}$ and IGF-I ( $r=0.499, p<0.0001)$ or IGFBP-3 $(r=0.274, p<$ $0.0001)$ among all girls and between T and IGF-I $(r=0.764$ $p<0.0001)$ or IGFBP-3 $(r=0.551, p<0.0001)$ among all
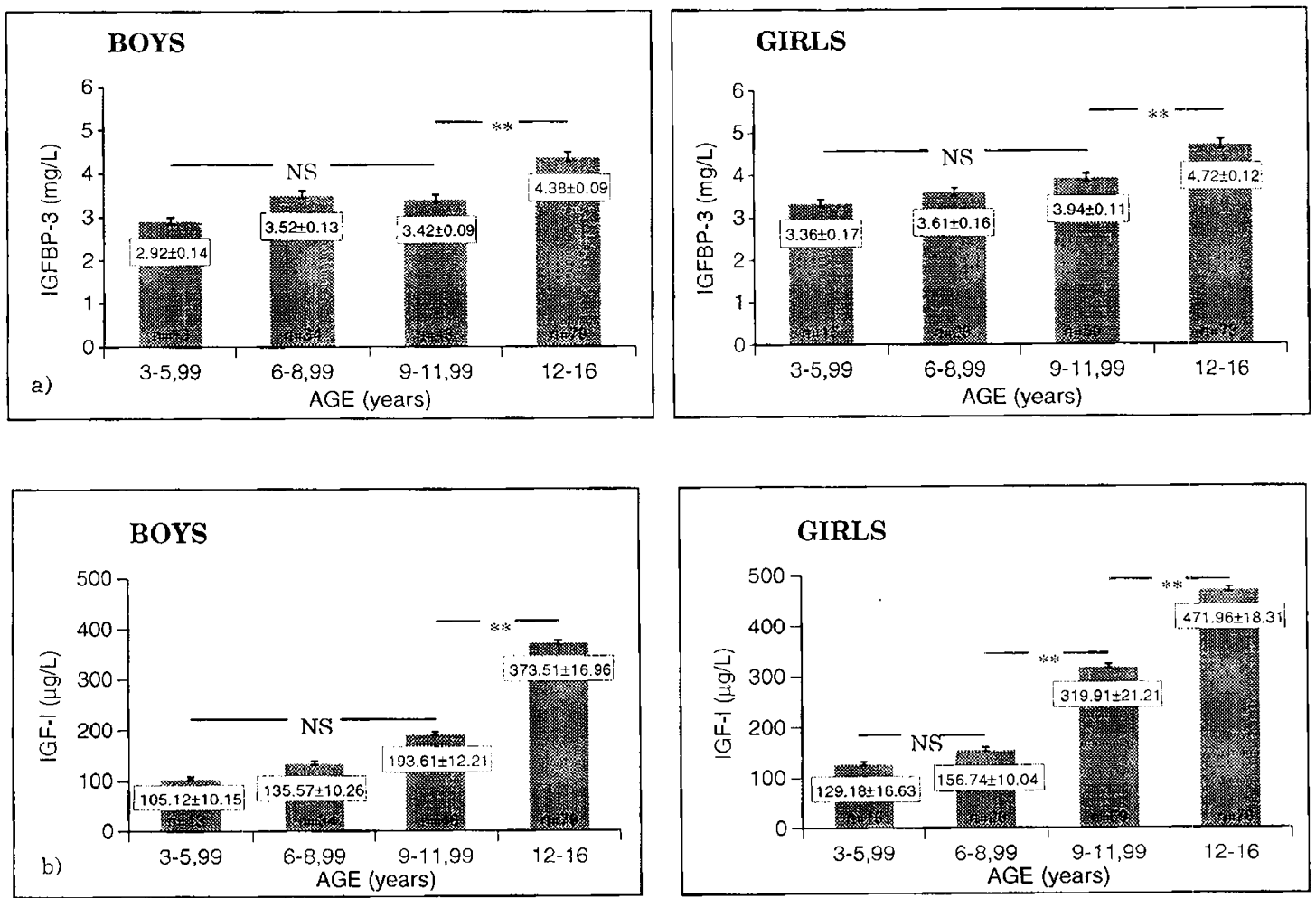

Figure 1. $a$, Mean \pm SEM levels of IGFBP-3 against age in the four age groups of children studied. ${ }^{* *} p<0.0001$ (by ANOVA). $b$, Mean \pm SEM levels of IGF-I against age in the four age groups of children studied. ${ }^{*} p<0.0001$ (by ANOVA). 


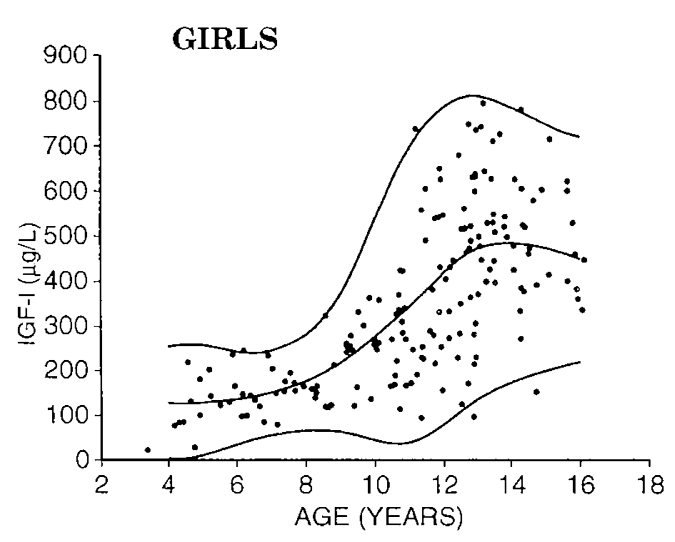

BOYS

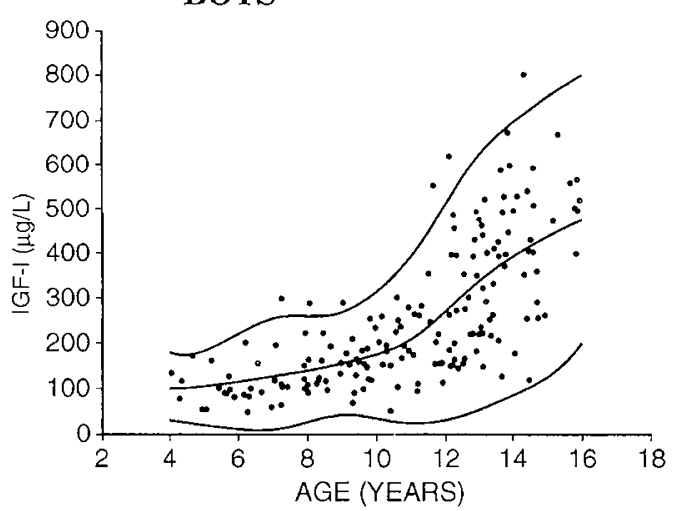

GIRLS

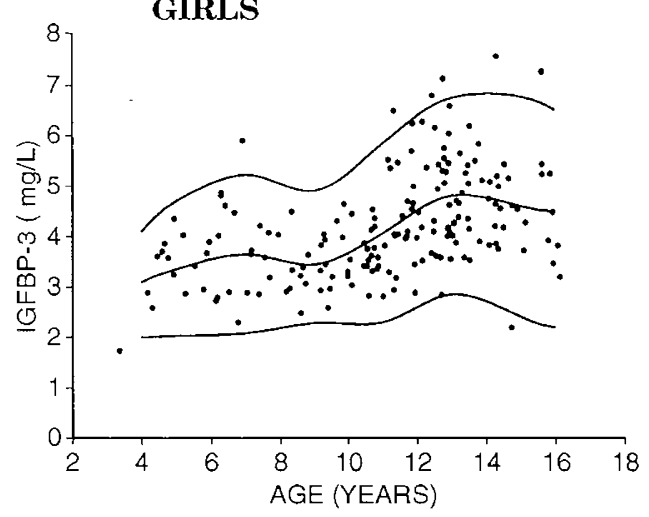

BOYS

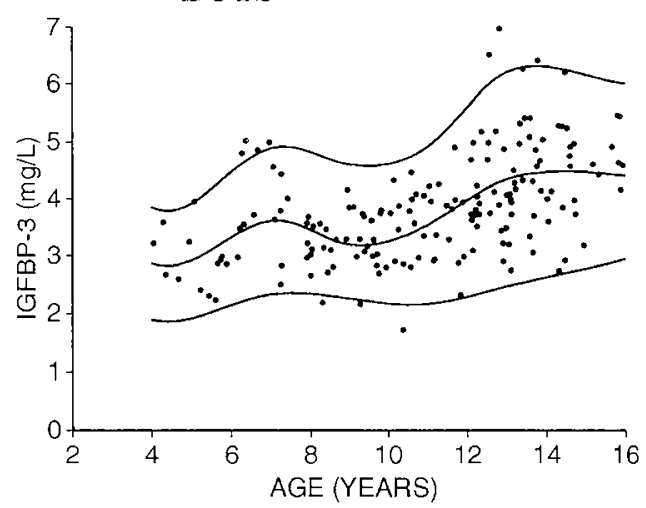

Figure 2. IGF-I and IGFBP-3 levels in girls and boys related to the age-dependent normal range. For both IGFBP-3 and IGF-I levels the normal range is given by the 5 th, 50 th, and 95 th percentile.

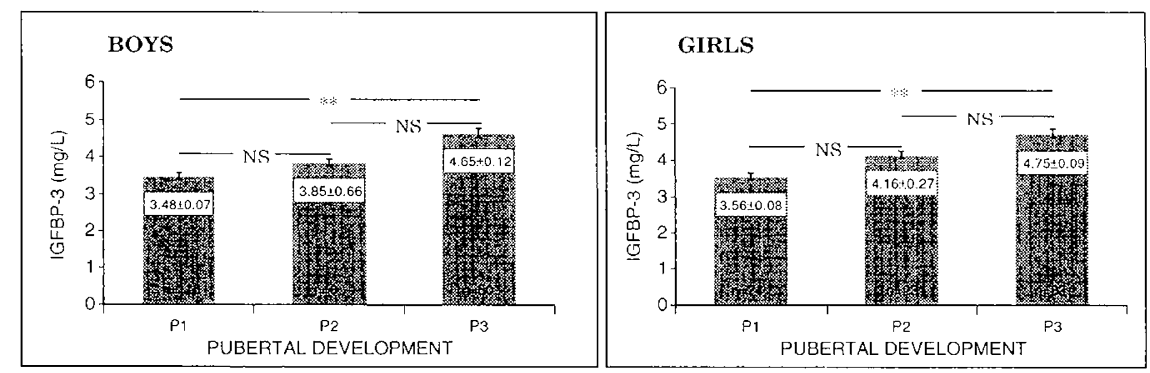

Figure 3. Mean \pm SEM levels of IGFBP-3 in the three stages of pubertal development studied. $P I$, prepubertal; $P 2$, early pubertal; $P 3$, overt pubertal. ** $p<$ 0.0001 (by ANOVA).

boys were observed. However, when the subjects were divided into prepubertal and pubertal stages of development, a significative linear correlation was observed in prepubertal children between IGF-I and sex steroids levels ( $\mathrm{E}_{2}$ or $\mathrm{T}$ ), but only in prepubertal boys for IGFBP-3 and $\mathrm{T}$ levels. A significative weak linear correlation between $\mathrm{E}_{2}$ levels and IGF-I $(r=0.30$, $p<0.05$ ) was also found in pubertal boys (Table 2). Multiple correlation analysis was then performed, using IGF-I or IGFBP-3 as independent variables and age and sex steroid levels as dependent variables. The significative correlation between IGF-I with $\mathrm{E}_{2}$ or $\mathrm{T}$ was not modified in prepubertal girls and boys, respectively, whereas in pubertal boys we observed a lack of significative correlation $(p=0.069)$ between IGF-I and $\mathrm{E}_{2}$ when including age. Regarding IGFBP-3, we observed a significative correlation between this variable and $\mathrm{T}$ in prepubertal boys and a lack of correlation between IGFBP-3 and $\mathrm{E}_{2}$ in prepubertal and pubertal girls (Table 3).

Association between IGF-I and IGFBP-3. IGFBP-3 levels were highly correlated to IGF-I levels in the whole sample of children $(r=0.617, p<0.0001)$ as well as among both girls $(r=0.67, p<0.0001)$ and boys $(r=0.505, p<0.0001)$. However, when subjects were divided into prepubertal and pubertal stages of development, a significative correlation was observed among prepubertal girls $(r=0,25, p=0.031)$ and boys $(r=0.30 p=0.0011)$ but only among pubertal girls $(r=$ $0.40, p=0.002$ ) (Fig. 5).

When we used $\log$ IGF-I and $\log$ IGFBP-3 to study the data, a significative correlation between both parameters was also observed in girls $(r=0.676, p=0.0001)$ and boys $(r=0.526$, $p=0.0001)$. After being divided into prepubertal and pubertal 

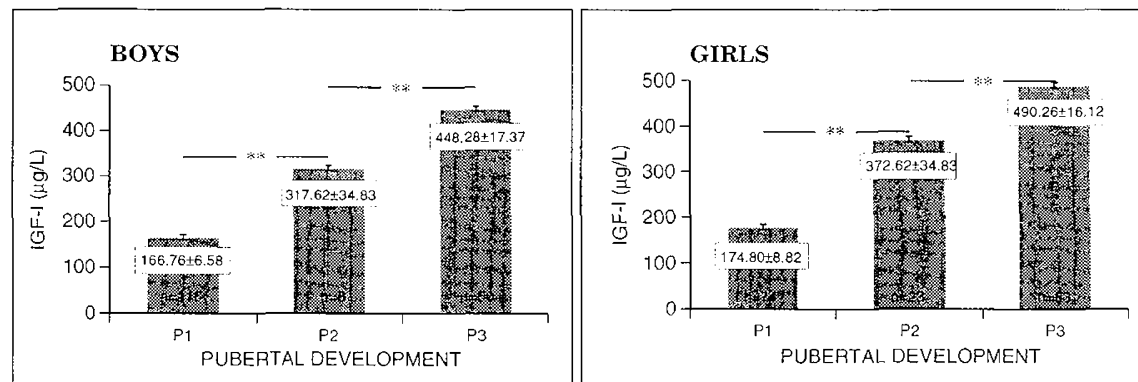

Figure 4. Mean \pm SEM levels of IGF-I in the three stages of pubertal development studied. $P 1$, prepubertal; $P 2$, early pubertal; $P 3$, overt pubertal. **p $<0.0001$ (by ANOVA)

Table 2. Simple linear correlation coefficients between sex steroid levels and IGFBP-3 or IGF-I

\begin{tabular}{|c|c|c|c|c|c|c|c|c|}
\hline \multirow[b]{3}{*}{ Steroid } & \multicolumn{4}{|c|}{ IGFBP-3 } & \multicolumn{4}{|c|}{ IGF-I } \\
\hline & \multicolumn{2}{|c|}{ Prepubertal } & \multicolumn{2}{|c|}{ Overt pubertal } & \multicolumn{2}{|c|}{ Prepubertal } & \multicolumn{2}{|c|}{ Overt pubertal } \\
\hline & $\begin{array}{c}\text { Girls } \\
(n=74)\end{array}$ & $\begin{array}{c}\text { Boys } \\
(n=116)\end{array}$ & $\begin{array}{c}\text { Girls } \\
(n=83)\end{array}$ & $\begin{array}{c}\text { Boys } \\
(n=50)\end{array}$ & $\begin{array}{c}\text { Girls } \\
(n=74)\end{array}$ & $\begin{array}{c}\text { Boys } \\
(n=116)\end{array}$ & $\begin{array}{c}\text { Girls } \\
(n=83)\end{array}$ & $\begin{array}{c}\text { Boys } \\
(n=50)\end{array}$ \\
\hline $\mathrm{E}_{2}$ & 0.074 & & 0.122 & 0.119 & $0.385^{* * *}$ & & 0.113 & $0.30 *$ \\
\hline $\mathrm{T}$ & & $0.33^{* * *}$ & & 0.082 & & $0.484^{* * *}$ & & 0.08 \\
\hline
\end{tabular}

$* p<0.05$

$* * p<0.005$

$* * * p<0.0005$.

Table 3. Multiple regression analysis of IGFBP-3 or IGF-I vs sex steroids and age

\begin{tabular}{|c|c|c|c|c|c|c|c|c|}
\hline & \multicolumn{4}{|c|}{ IGFBP-3 } & \multicolumn{4}{|c|}{ IGF-I } \\
\hline & \multicolumn{2}{|c|}{ Prepubertal } & \multicolumn{2}{|c|}{ Overt pubertal } & \multicolumn{2}{|c|}{ Prepubertal } & \multicolumn{2}{|c|}{ Overt pubertal } \\
\hline & Girls & Boys & Girls & Boys & Girls & Boys & Girls & Boys \\
\hline$r$ & 0.122 & 0.336 & 0.153 & 0.231 & 0.545 & 0.574 & 0.175 & 0.361 \\
\hline$p$ value & NS & 0.0012 & NS & NS & 0.0001 & 0.0001 & NS & NS \\
\hline $\mathrm{E}_{2}$ & NS & & NS & NS & $p<0.05$ & & NS & NS \\
\hline $\mathrm{T}$ & & $p<0.005$ & & NS & & $p<0.005$ & & NS \\
\hline Age & NS & NS & NS & NS & $p<0.0005$ & $p<0.0005$ & NS & NS \\
\hline
\end{tabular}

stages of development, significative correlation was maintained among prepubertal girls $(r=0.361, p=0.0016)$ and boys $(r=0.292, p=0.0015)$ but only among pubertal girls $(r=0.468, p=0.0001)$.

Relationship between body composition and IGF-I or IGFBP-3. The effect of height-SDS, weight-SDS, and WFHA on IGFBP-3-SDS or IGF-I-SDS levels, statistically adjusted for sex and age, was evaluated by multiple and stepwise logistic regression analyses. Serum IGFBP-3-SDS or IGF-ISDS levels were significatively correlated only to WFHA in prepubertal children (Table 4).

\section{DISCUSSION}

We observed higher IGFBP-3 levels than the reported by Blum et al. (7) in prepubertal children. The same antibody has been used in both studies but a different RIA method. Our data agree with recently reported data of Argente et al. (16), who used the same commercial RIA kit as was used in the present study.

As was demonstrated in earlier studies $(10,11,17)$ significative association between IGF-I or IGFBP-3 and pubertal development is established. Our results agree with these find- ings and extend the Wilson et al. $(11,17)$ data, which were obtained only for female subjects, to male subjects.

A significative correlation between IGF-I and IGFBP-3 with chronologic age was observed in the whole sample of children which agrees with previous observations by Blum et al. $(7,18)$ and Juul et al. (19). However, IGFBP-3 levels during normal adolescence are better associated to the pubertal stage than with chronologic age as occur with the IGF-I levels (17, 18, 20). To avoid the semiquantitative and necessarily subjective Tanner scale and based on our own experience and previous studies (21-24), we classified the pubertal stages of development according to gonadal steroid levels. In this way a significative correlation between $\mathrm{T}$ and IGF-I or IGFBP-3 levels in prepubertal boys, and between $\mathrm{E}_{2}$ and IGF-I levels in prepubertal girls, was observed. These data were not previously reported. The lack of correlation in pubertal children was probably due to the heterogeneity of pubertal states. Moreover, in female subjects we lack information on the phase of the menstrual cycle. Our findings in male subjects agree with an earlier report by Weissberger and Ho (25). Their data suggested that $\mathrm{T}$ interacts with the somatotropic axis and was at least partially dependent on aromatization of $T$ to $E_{2}(26)$. In 

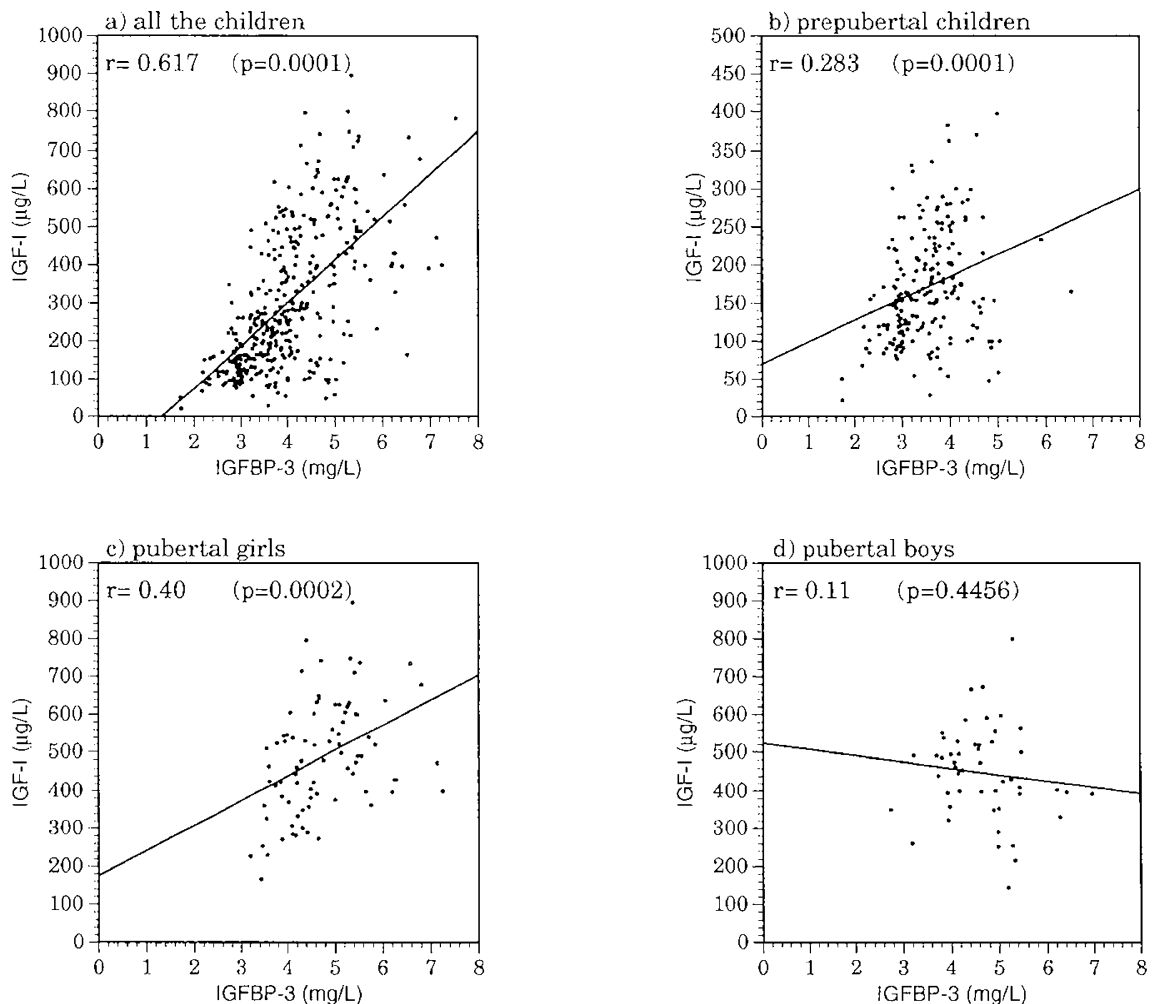

Figure 5. IGFBP-3 levels $v s$ IGF-I in prepubertal and pubcrtal children. $a$, In all the children $(n=354, r=0.617, p<0.0001)$. $b$, In prepubertal children $(n=190, r=0.283, p<0.0001)$. $c$, In pubertal girls $(n=83, r=0.40, p<0.0001)$. $d$, In pubertal boys $(n=50, r=0.11, p=0.445)$.

Table 4. Multiple regression analysis of SDS-IGFBP-3 or SDS-IGF-I vs SDS-height, SDS-weight, WFHA, and age

\begin{tabular}{|c|c|c|c|c|c|c|}
\hline & \multicolumn{3}{|c|}{ SDS-IGFBP-3 } & \multicolumn{3}{|c|}{ SDS-IGF-1 } \\
\hline & \multirow{2}{*}{$\begin{array}{l}\text { Prepubertal } \\
\text { girls and boys }\end{array}$} & \multicolumn{2}{|c|}{ Overt pubertal } & \multirow{2}{*}{$\begin{array}{l}\text { Prepubertal } \\
\text { girls and boys }\end{array}$} & \multicolumn{2}{|c|}{ Overt pubertal } \\
\hline & & Girls & Boys & & Girls & Boys \\
\hline$r$ & 0.329 & 0.309 & 0.118 & 0.444 & 0.288 & 0.215 \\
\hline$p$ value & 0.0003 & NS & NS & 0.0001 & NS & NS \\
\hline SDS-hcight & NS & NS & NS & NS & NS & NS \\
\hline SDS-weight & $p<0.05$ & NS & NS & NS & NS & NS \\
\hline WFHA & $p<0.005$ & NS & NS & $p<0.05$ & NS & NS \\
\hline Age & $p<0.005$ & NS & NS & $p<0.0005$ & NS & NS \\
\hline
\end{tabular}

fact, when we studied the linear correlation between IGF-I or IGFBP-3 and $\mathrm{E}_{2}$ levels in pubertal boys, significant correlation only between IGF-I and $\mathrm{E}_{2}$ was observed, in agreement with a recent report by $\mathrm{Ho}$ et al. (27). The lack of significative correlation in pubertal boys between IGF-I and E2, when including age in multivariate regression analyses, could be due to the fact that in the pubertal stage the number of subjects is too low. These data suggested that other factors besides GH or sex steroid hormone levels might contribute to IGFBP3 level regulation.

Although the physiologic regulation of IGFBP-3 concentration is still unclear, serum IGFBP-3 is variably correlated with the IGF-I concentration. In fact, our results show a higher correlation between IGF-I and IGFBP-3 than the that from the data reported by Wilson et al. (17), a similar correlation as in the recent data from Moshe et al. (28), and a lower correlation than results reported by Blum et al. (18). In the present study, however, although IGF-I and IGFBP-3 levels were signifi- cantly correlated among girls, either in the whole group or when girls were divided into prepubertal and pubertal stages of development, among boys significant correlation between these variables was observed only in prepubertal subjects. The lack of correlation between IGF-I and IGFBP-3 in pubertal boys is not easily explained. Major differences between the various pubertal events in boys and girls, particularly regarding timing, could be explained by the different association between IGF-I and IGFBP3 according to gender (24). Further studies will be necessary to clarify this discordance.

Data regarding the association between physical measures and IGFBP-3 levels, particularly in prepubertal children (18), are scarce. We found a weak statistically significant association between WFHA with serum IGFBP-3-SDS concentrations among the whole sample of prepubertal children. In contrast, we did not find any relationship between these parameters and IGFBP-3-SDS levels in pubertal girls and boys; our data extend the earlier findings by Wilson et al. (17) in female 
subjects. Furthermore, IGF-I-SDS levels are also strongly associated with WFHA only in prepubertal children. It has been reported that nutritional status is important in the regulation of IGF-I levels, but a possible hypothesis is that, during puberty, concomitant changes in nutritional status or body composition are counter-regulated by the effects of sex steroids on IGF-I. The present findings suggest that neither IGFBP-3 levels nor IGF-I levels are a clinically useful index of nutritional status among normal pubertal children.

In summary, the present data suggest that interpretation of the IGFBP-3 concentrations during adolescence requires knowledge of gonadal steroid levels. We believe that determination of IGFBP-3 levels is useful for clinical proposes in prepubertal children. Further studies are necessary to clarify the underlying mechanism involved in IGF-I and IGFBP-3 level regulation.

Acknowledgments. The authors thank Ignacio Alvarez Cantalapiedra, M.D., for his assistance in the statistical analyses and Anthony John Rostron, B.Sc.(Hons.), for his help in proofreading the text.

\section{REFERENCES}

1. Rosenfeld RG, Lamson G, Pham H, Oh Y, Conover C, De Leon DD, Donovan SM, Ocrant I, Giudice L 1990 Insulin-like growth factor binding proteins. Recent Prog Horm Res 46:99-163

2. Baxter RC, Martin JL 1989 Binding proteins for the insulin-like growth factors: structurc, regulation and function. Prog Growth Factor Res 1:49-68

3. Wood WI, Cachianes G, Henzel WJ, Winslow GA, Spencer SA, Hellmiss R, Martin J, Baxter RC 1988 Cloning and expression of the growth hormone-dependent insulin-like growth factor-binding protein. Mol Endocrinol 2:1175-1185

4. Spratt SK, Tatsuno GP, Sommer A 1991 Cloning and characterization of bovine insulin-like growth factor binding protein-3. Biochem Biophys Res Commun 165:907-912

5. Binoux M, Hosscnlopp P 1988 Insulin-like growth factor (IGF) and IGF-binding proteins: comparison of human serum and lymph. J Clin Endocrinol Mctab 67:509514

6. Martin JL, Baxter RC 1985 Antibody against acid-stable insulin-like growth facto binding protein detects 150,000 mol wt growth hormone-dependent complex in human plasma. J Clin Endocrinol Metab 61:799-801

7. Blum WF, Ranke MB, Kictzmann K, Gauggel E, Zciscl HJ, Bicrich JR 1990 A specific radioimmunoassay for the growth hormone GH-dependent sometomedinbinding protcin: Its usc for diagnosis of GH deficiency. J Clin Endocrinol Metab 70:1292-1298

8. Blum WF, Rankc MB 1990 Insulin-like growth factor binding proteins (IGFBPs) with special reference to IGFBP-3. Acta Pacdiatr Scand Suppl 367:55-62

9. Luna AM, Wilson DM, Wibbelsman CJ, Brown RC, Nagashima RJ, Hintz RL, Roscnfeld RG 1983 Somatomedins in adolescence: A cross sectional study of the effect of pubcrty on plasma insulin-like growth factors I and II levels. J Clin Endocrinol Metab 57:268-271
10. Rosenfeld RI, Furlanctto R, Bock D 1983 Relationship of somatomedin-C concentrations to pubertal changes. J Pediatr 103:723-728

11. Wilson DM, Killen JD, Hammer LD, Litt IF, Vosti C, Miner B, Hayward C, Taylor CB 1991 Insulin-like growth factor-I as a reflection of body composition, nutrition, and puberty in 6th and 7th grade girls. J Clin Endocrinol Metab 73:907-912

12. Phillips LS 1986 Nutrition, somatomedins, and the brain. Metabolism 35:78

13. Hintz RL, Suskind R, Amatayakul K, Thanangkul O, Olson R 1987 Plasma somatomedin and growth hormone values in children with protein-calorie malnutrition. J Pediatr 92:153-156

14. Clemmons DR, Underwood LE, Dickerson RN, Brown RO, Hak LJ, MacPhee RD Heizer WD 1985 Usc of plasma somatomedin-C/insulin-like growth factor I measurements to monitor the response to nutritional repletion in malnourished patients. Am J Clin Nutr 41:191-198

15. Unterman TG, Vazquez RM, Slas AJ, Martyn PA, Phillips LS 1985 Nutrition and somatomedin. XIII. Usefulness of somatomedin-C in nutritional assessment. Am J Mcd 78:228-234

16. Argente J, Barrios V, Pozo J, Muñoz MT, Hervás F, Stene M, Hernandez M 1993 Normative data for IGFs, IGF-binding proteins, and growth hormone-binding protein in a healthy Spanish pediatric population: Age- and sex-related changes. $\mathrm{J}$ Clin Endocrinol Metab 77:1522-1528

17. Wilson DM, Stene MA, Killen JD, Hammer LD, Lill IF, Hayward C, Taylor CB 1992 Insulin-likc growth factor binding protein-3 in normal pubertal girls. Acta Endocrinol 126:381-386

18. Blum WF, Albertsson-Wikland K, Rosberg S, Ranke MB 1993 Serum levels of IGF-I and IGFBP-3 reflect spontaneous growth hormonc secretion. J Clin Endocrinol Metab $76: 1610-1615$

19. Juul A, Bang P, Hertel NT, Main K, Dalgaard P, Jorgensen K, Muller J, Hall K, Skakkebaek NE 1994 Serum insulin-like growth factor-I in 1030 healthy children, adolescents, and adults: relation to age, sex, stage of puberty, testicular size, and body mass index. J Clin Endocrinol Mctab 78:744-752

20. Massa G, Bouillon R, and Vanderschueren-Lodeweycks M 1992 Serum levels of growth hormone-binding protein and insulin-like growth factor-I during puberty. Clin Endocrinol 37:175-180

21. Cuttler L, Rosenfield RL, Ehrmann DA, Kreiter M, Burstein S, Cara JF, Levitsky LL 1993 Maturation of gonadotropin and sex steroid responses to gonadotropin-rclcasing hormone agonist in males. J Clin Endocrinol Metab 76:362-366

22. Kletter GB, Padmanabhan V, Brown MB, Reiter EO, Sizonenko PC, Beitins Z 1993 Serum bioactive gonadotropins during male puberty: a longitudinal study. J Clin Endocrinol Metab 76:432-438

23. Maruyama $Y$, Aoki $N$, Suzuki $Y$, Ohno $Y$, Imamura $M$, Saika $T$, Sinohara $H$, Yamamoto $T 1987 \mathrm{Sex}$-stcroid-binding plasma protein (SBP), testosterone, oestradio and dehydrocpiandrosterona (DHEA) in prepuberty and puberty. Acta Endocrinol (Copenh) 114:60-67

24. Rogol AD 1992 Growth and growth hormone secretion at puberty: The role of gonadal steroid hormones. Acta Paediatr Suppl 383:15-20

25. Weissberger AJ, Ho KY 1993 Activation of the somatotropic axis by testosterone in adult males: Evidence for the role of aromatization. J Clin Endocrinol Mctab $76: 1407-1412$

26. Keenan BS, Richards GE, Ponder SW, Dallas JS, Nagamani M, and Smith ER 1993 Androgen-stimulated pubertal growth: The effect of testosterone and dihydrotestosterone on growth hormone and insulin-like growth factor-I in the treatment of short stature and delayed puberty. J Clin Endocrinol Mctab 76:996-1001

27. Ho KY, Evans WS, Blizzard RM, Veldhuis JD, Merriam GR, Samojlik E, Furlanetto R, Rogol AD, Kaiser DL, Thorner MO 1987 Effects of sex and age on the 24-hour profile of growth hormone secretion in man: Importance of endogenous estradiol concentrations. J Clin Endocrinol Metab 64:51-58

28. Moshe P, Stuart AC, Avinoam Kowarski, Stene M 1993 Plasma IGFBP-3 and its relationship with quantitative growth hormone secretion in short children. Clin Endocrinol 39:427-432 